\title{
Auxin as a player in the biocontrol of Fusarium head blight disease of barley and its potential as a disease control agent
}

\author{
Carloalberto Petti ${ }^{1,2^{*}+}$, Kathrin Reiber ${ }^{1+}$, Shahin S Ali ${ }^{1}$, Margaret Berney ${ }^{1}$ and Fiona M Doohan ${ }^{3}$
}

\begin{abstract}
Background: Mechanisms involved in the biological control of plant diseases are varied and complex. Hormones, including the auxin indole acetic acid (IAA) and abscisic acid (ABA), are essential regulators of a multitude of biological functions, including plant responses to biotic and abiotic stressors. This study set out to determine what hormones might play a role in Pseudomonas fluorescens - mediated control of Fusarium head blight (FHB) disease of barley and to determine if biocontrol-associated hormones directly affect disease development.

Results: A previous study distinguished bacterium-responsive genes from bacterium-primed genes, distinguished by the fact that the latter are only up-regulated when both $P$. fluorescens and the pathogen Fusarium culmorum are present. In silico analysis of the promoter sequences available for a subset of the bacterium-primed genes identified several hormones, including IAA and ABA as potential regulators of transcription. Treatment with the bacterium or pathogen resulted in increased IAA and ABA levels in head tissue; both microbes had additive effects on the accumulation of IAA but not of ABA. The microbe-induced accumulation of ABA preceded that of IAA. Gene expression analysis showed that both hormones up-regulated the accumulation of bacterium-primed genes. But IAA, more than ABA up-regulated the transcription of the ABA biosynthesis gene NCED or the signalling gene Pi2, both of which were previously shown to be bacterium-responsive rather than primed. Application of IAA, but not of ABA reduced both disease severity and yield loss caused by F. culmorum, but neither hormone affect in vitro fungal growth.

Conclusions: Both IAA and ABA are involved in the P. fluorescens-mediated control of FHB disease of barley. Gene expression studies also support the hypothesis that IAA plays a role in the primed response to F. culmorum. This hypothesis was validated by the fact that pre-application of IAA reduced both symptoms and yield loss asssociated with the disease. This is the first evidence that IAA plays a role in the control of FHB disease and in the bacterial priming of host defences.
\end{abstract}

Keywords: Hormone, IAA, ABA, Pseudomonas fluorescens, Biocontrol, Fusarium head blight

\section{Background}

Biological control bacteria regulate the capacity of plants to resist pathogen attack through diverse mechanisms [1-6]. Recently, Zhang et al. (2011) showed that bacteriaresponsive plant microRNAs regulate plant innate

\footnotetext{
*Correspondence: Carloalberto_petti@hotmail.com

${ }^{\dagger}$ Equal contributors

${ }^{1}$ Molecular Plant-Pathogen Interaction Group, School of Biology and Environmental Science, University College Dublin, Science Education and Research Centre West, Belfield, Dublin, Ireland

${ }^{2}$ Current address: Department of Horticulture, Science Centre North,

University of Kentucky, Lexington, Kentucky 40502, USA

Full list of author information is available at the end of the article
}

immunity by modulating the plant hormone network [7]. Phytohormones are key determinants of a plants' ability to tolerate abiotic and biotic stress (reviewed by [8]). They are the effector molecules responsible for signal perception/transduction, cellular homeostasis and gene expression. As a consequence, they play an important role in plant responses to, and resistance against, disease.

Hormones and hormone-synthetic analogs have been used to prime plants such that they are prepared to mount defence responses against various pathogens. The induced systemic resistance (ISR) pathway is stimulated during necrotrophic bacterial attack and is primed by

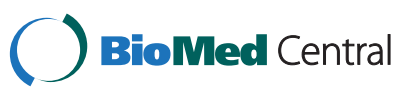


biocontrol species such as Pseudomonas to protect the plant from pending attack, possibly by increasing the plants susceptibility to the ISR-regulating hormone jasmonic acid (JA) [9]. The priming of the ISR response is linked to JA and ethylene (ET), yet significant accumulation of these hormones has not been reported in ISRexpressing plants [3]. Bacterium-mediated ISR is not dependent upon the induction of the defence hormone salicylic acid (SA), at least for the rhizobacterium strain P. fluorescens WCS417r $[10,11]$. Application of the auxin $\beta$-aminobutyric acid resulted in induced resistance to Alternaria brassicola and priming for callose deposition and resistance [12]. Priming of callose deposition was dependent on the classical plant defence hormone abscisic acid (ABA). Other hormones such as the the auxin indole acetic acid (IAA), cytokinins and brassinosteroids modulate host defence responses [13], but have not yet been specifically linked to defence priming.

A number of $P$. fluorescens strains have already been reported to prime plants by initiating defence responses to subsequent pathogen attacks [4]. P. fluorescens strain MKB158 had the ability to induce local and systemic responses in wheat and barley tissue, resulting in enhanced resistance to Fusarium seedling blight and head blight (FSB and FHB) disease [14-17]. The objective of this study was to determine what hormones are involved in the defence responses to FHB in barley that are primed by the bacterium $P$. fluorescens strain MKB158. Based on in silico analysis of the upstream regions of genes involved in the primed response [17] we chose to determine whether the hormones $A B A$ and IAA play a role in the biocontrol of FHB disease by $P$. fluorescens. Based on the assessment of both hormone levels and their effect on both the regulation of plant genes activated by the biocontrol bacterium and the development of FHB disease symptoms, we draw conclusions regarding the contribution of IAA and ABA to the local defence responses of barley plants primed by $P$. fluorescens. Furthermore, we highlight the potential of IAA as a treatment for the control of FHB disease.

\section{Results}

ABA- and GA-responsive elements are highly represented in potentiated genes

We previously identified 86 barley genes that were primed by $P$. fluorescens to respond to $F$. culmorum [17]. Barley genome sequence was available for 39 (45\%) of these genes (see Additional file 1: Table S1). In silico analysis of upstream promoter regions indicated that 38 of these contained hormone-responsive elements (Additional file 1: Table S1). ABA- and GAresponsive elements were detected in all of these upstream regions, $\mathrm{ABA}$ being most commonly detected (between 1-12 ABA-responsive elements per upstream region analysed) (Additional file 1: Table S1). Elements responsive to the hormones AUX/IAA and SA were also frequent, being detected in 64 and $56 \%$ of putative promoter regions, respectively. JA-responsive elements were identified within the upstream region of a histone $\mathrm{H} 4$ gene and genes involved in defence - glutathiones, peroxidases, MLA12 and PDR-type ABC transporters.

\section{$A B A$ and IAA levels are modulated by both the biocontrol} agent and the pathogen

Experiments were conducted in order to determine if ABA or IAA accumulation varied during the early stages of FHB disease development in barley and if this was affected by application of the biocontrol bacterium $P$. fluorescens ( $24 \mathrm{~h}$ pre-pathogen treatment). ABA was produced in response to both bacterium and fungal treatment as early as $4 \mathrm{~h}$ post-pathogen treatment. ABA production (Figure 1a) was induced by both bacterial and fungal treatment. Noteworthy was the fact that at any of the time points tested, ABA levels in plants treated with both the bacterium plus fungus were not significantly different from the levels determined in the bacterium-treated plants $(P>0.05)$. The combined effects of both agents on ABA accumulation were neither additive nor synergistic. ABA production peaked at $24 \mathrm{~h}$ post-fungal inoculation and by $48 \mathrm{~h}$ it had not returned to basal levels.

Similar to ABA, IAA was produced in response to both $P$. fluorescens and F. culmorum as early as $4 \mathrm{~h}$ postpathogen treatment. Unlike ABA, additive effects of the bacterium and fungus on hormone accumulation could account for the levels of IAA detected in plants treated with both agents at $24 \mathrm{~h}$; at $12 \mathrm{~h}$ effects were at least additive and potentially synergistic (Figure 1b). By $12 \mathrm{~h}$ post-Fusarium inoculation, IAA production levels were 2.8-fold higher in bacterium as compared to control samples and 1.3-fold greater than the fungus samples $(P<0.05)$. But IAA levels were 5.8 -fold higher in plants treated with both bacterium and fungus as compared to control plants $(P<0.05)$. Similar results were observed at $24 \mathrm{~h}$ post-fungal inoculation. But, by $48 \mathrm{~h}$ post-fungal inoculation, IAA levels were similar across all treatments $(\mathrm{P}>0.05)$ (Figure $1 \mathrm{~b})$.

\section{Bacterium-potentiated genes are up-regulated in response to both IAA and ABA}

Previously we discriminated two set of plant genes activated in response to $P$. fluorescens strain MKB158; one set were transcriptionally activated by the bacterium alone and the other set were primed by the bacterium to respond to the pathogen $F$. culmorum, respectively known as bacterium-responsive and bacterium-potentiated genes [17]. We hypothesised that if either ABA or IAA were involved in priming then, in pathogen-treated heads, they 


\section{a}

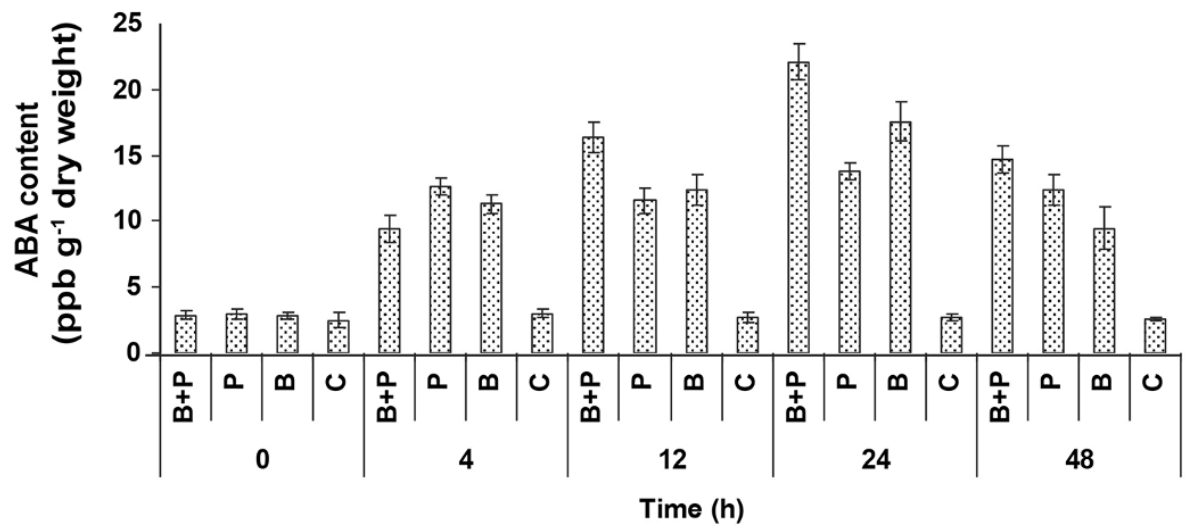

b

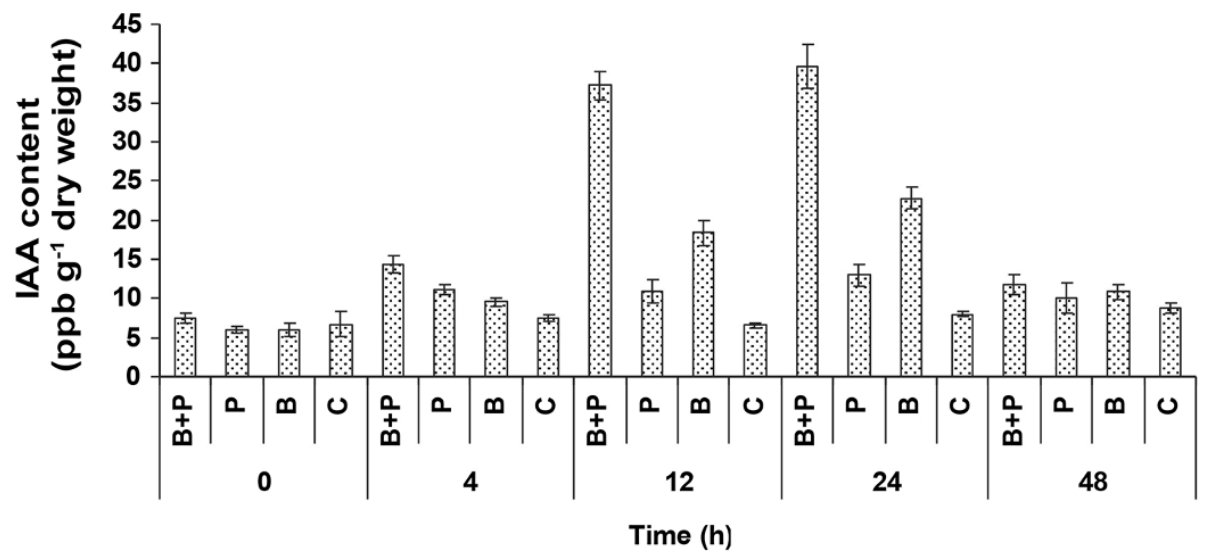

Figure 1 Effect of pre-treatment with Pseudomonas fluorescens strain MKB158 on the accumulation of (a) abscisic acid (ABA) and (b) indole-3-acetic acid (IAA) in barley head tissues inoculated with Fusarium culmorum. Heads were treated with cells of $P$. fluorescens strain MKB158 or water $24 \mathrm{~h}$ pre-inoculation with conidia of F. culmorum strain FCF 200. Heads were harvested at various time points post-pathogen treatment, hormones were extracted and quantified by ELISA analysis. Treatments codes: C, controls treated with water and Tween20; $\mathrm{B}$, bacterium plus Tween20; P, pathogen plus Tween20; B+P, bacterium plus pathogen. Results are based on two biological replicates, each containing 4 bulked technical replicates per treatment. Bars indicate standard deviation.

may up-regulate potentiated genes but not necessarily bacterium-responsive genes. Potentiated genes studied were defence genes nsLTP, CI-1B, Tip3:1, Paz1 and ZnMT [17]. Bacterium-responsive genes studied were NCED (a fundamental gene involved in the initial steps of ABA biosynthesis; [18,19] and a protein kinase Pi2 [20]. We assessed the effect of both IAA and ABA on the expression of the aforementioned potentiated and bacteriumresponsive genes in control (Tween20) and F. culmorum treated barley heads from 4 to $48 \mathrm{~h}$ post-treatment (Figure 2). Gene expression was highest at $12-24 \mathrm{~h}$ posttreatment with pathogen or Tween20 (controls). In the absence of the pathogen, both ABA and IAA up-regulated most genes but transcript levels were generally much lower than in pathogen-treated heads (Figure 2). In pathogen-inoculated heads, both IAA and ABA significantly up-regulated the potentiated genes and NCED $(P<0.05)$ (Figure $2 \mathrm{a}-2 \mathrm{f})$. PI2 was potentiated by ABA and by IAA to respond to F. culmorum, although the effects of ABA were more immediate and greater (Figure 2g). ABA effects on gene expression in pathogentreated tissue were generally more immediate than those of IAA, with the exception of ZnMT and NCED. ZnMT was the most IAA-responsive gene; it was the transcript that accumulated to the highest levels and, by $12 \mathrm{~h}$ postfungal treatment, it was up-regulated 24 fold in heads treated with Fusarium plus IAA as compared to Fusarium alone $(P<0.05)$ (Figure $2 \mathrm{~d})$.

\section{Exogenous application of IAA reduces FHB disease in barley}

Experiments were conducted in order to determine the effect of IAA and ABA application to barley heads on both visual symptoms and yield loss caused by the subsequent inoculation with F. culmorum. Pathogen inoculation resulted in $30 \%$ of spikelets displaying symptoms 

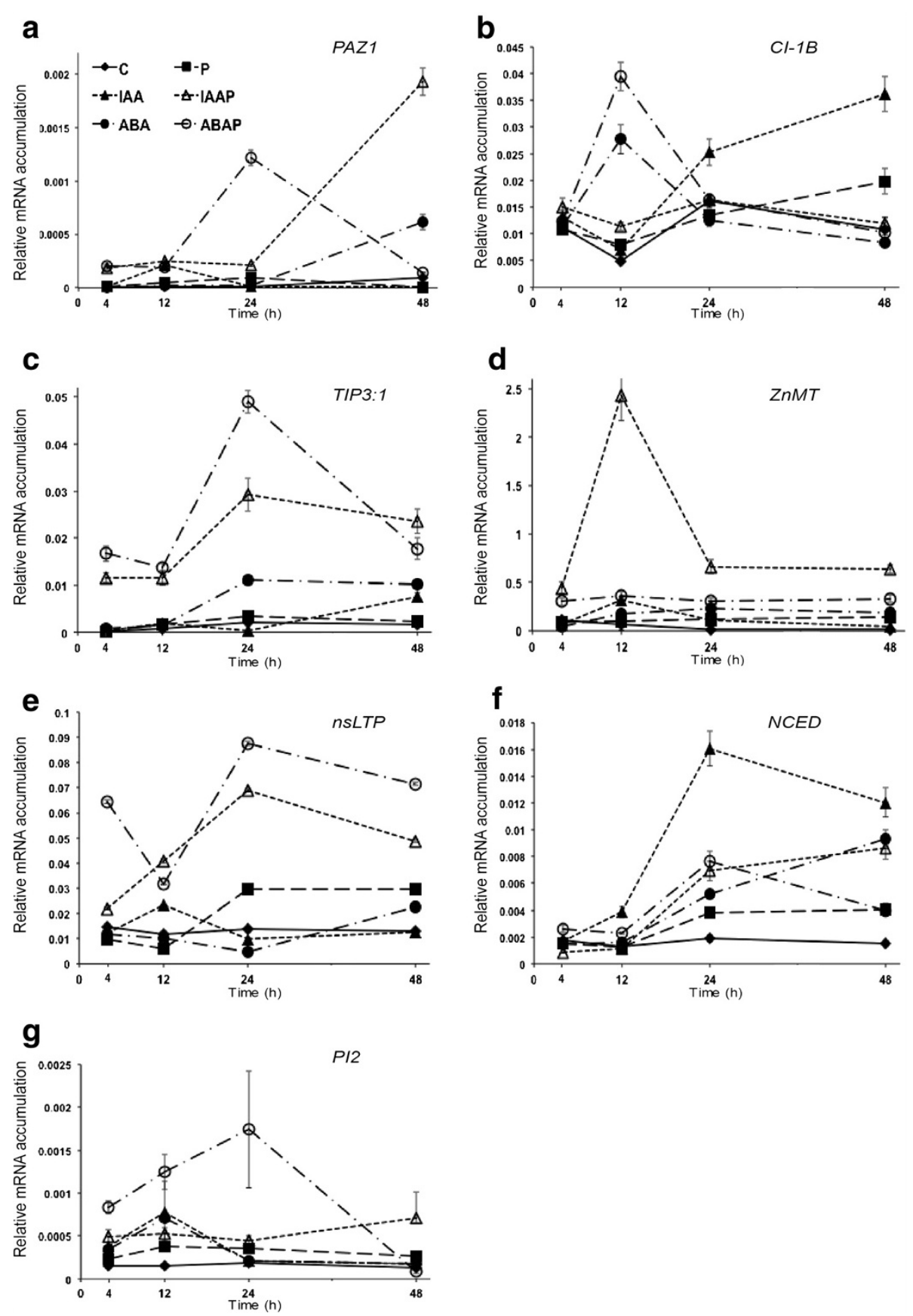

Figure 2 Temporal analysis of the effect of hormones abscisic acid (ABA) and indole-3-acetic acid (IAA) with or without application of pathogen Fusarium culmorum on the accumulation of select transcripts in heads of barley cultivar Lux. Transcripts represented are: (a) serpin Z4 (Paz1), (b) subtilisin-chymotrypsin inhibitor (Cl-1B), (c) tonoplast aquaporin (TIP3:1), (d) zinc methallothionin-like protein (ZnMT), (e) putative non-specific lipid transfer protein (nsLTP), (f) nine-cis-epoxycarotenoid dioxygenase NCED and (g) a signalling cascade protein (Pi2). Transcripts were previously identified by microarray analysis as being primed by the bacterium to accumulate in response to the pathogen at either 24 or $48 \mathrm{~h}$ post-pathogen treatment ( $\mathbf{a}$ to e) or as being activated by the bacterium only ( $\mathbf{f}$ and $\mathbf{g}$ ). Treatments: barley heads were treated with IAA, ABA or Tween20 (control treatment), and $24 \mathrm{~h}$ later, with pathogen (P) or Tween20. RNA extracted from treated head tissue at either 4 , 12, 24 or $48 \mathrm{~h}$ post-hormone or hormone and pathogen treatment was used for real-time RT-PCR analysis. ${ }^{\text {TTranscript accumulation was }}$ quantified as $2^{-(C T \text { target transcript-CTa-tubulin) }}$. Treatment codes: $C$, controls treated with Tween20; $P$, pathogen (F. culmorum); IAA, indole-3-acetic acid; $A B A$, abscisic acid; IAA + P; IAA plus pathogen; ABA+P, ABA plus pathogen. Results are based on two biological replicates, each including two techical replicates per treatment. Bars indicate standard error of mean. 
by GS 80 and a $7.6 \%$ reduction in 1000 grain weight $(P<0.001$, Figure 3$)$. ABA did not significantly reduce the disease symptoms or yield loss caused by the pathogen $(P>0.05$, Figure 3$)$. On the contrary, IAA reduced disease levels by $60 \%$ and negated the yield losses caused by the pathogen $(P<0.001)$. Grains were visually similar to those obtained for control plants (non-pathogen treated); in general they did not display the fungal growth and shrinkage evident in grains treated with pathogen (positive control) or ABA + pathogen (Figure 3d).

\section{No evidence that IAA and ABA directly inhibit fungal growth in vitro}

An in vitro plate assay was conducted in order to assess the effect of hormone supplementation on PDA on the growth of F. culmorum strain FCF200 (at 72 h postinoculation). Irrespective of the hormone concetration used, neither IAA nor ABA significantly affected the growth of the fungus, relative to control plates (Additional file 2: Figure S1).

\section{Discussion}

The importance of the hormones IAA and ABA as effectors molecules involved in the regulation of a variety of plant physiological mechanisms is well reported (reviewed in [8]. Moreover, an increasing body of evidence implicates a dualistic role of these hormones in plant defences and sensitivity to pathogens [21-26]. However, very little is known regarding their modulation by biocontrol agents. Herein we show that a biocontrol pseudomonad modulates IAA and ABA levels, that IAA and ABA either directly or indirectly influence the transcriptional regulation of genes involved in the response of the barley plants to these microbes, and that IAA can reduce the severity of FHB disease. The promoters of many of the bacteriumpotentiated genes also possessed both SA and JAresponsive elements in addition to those responsive to $\mathrm{ABA}$ and IAA. While JA plays a key role in ISR, SA is classically a SAR-associated hormone [27]. The SA response is generally concomitant with down-regulation of IAA $[28,29]$ the most abundant SA-responsive element within the promoters of bacterium-potentiated genes was TGACG, and this element is also responsive to IAA, biotic and abiotic stimuli
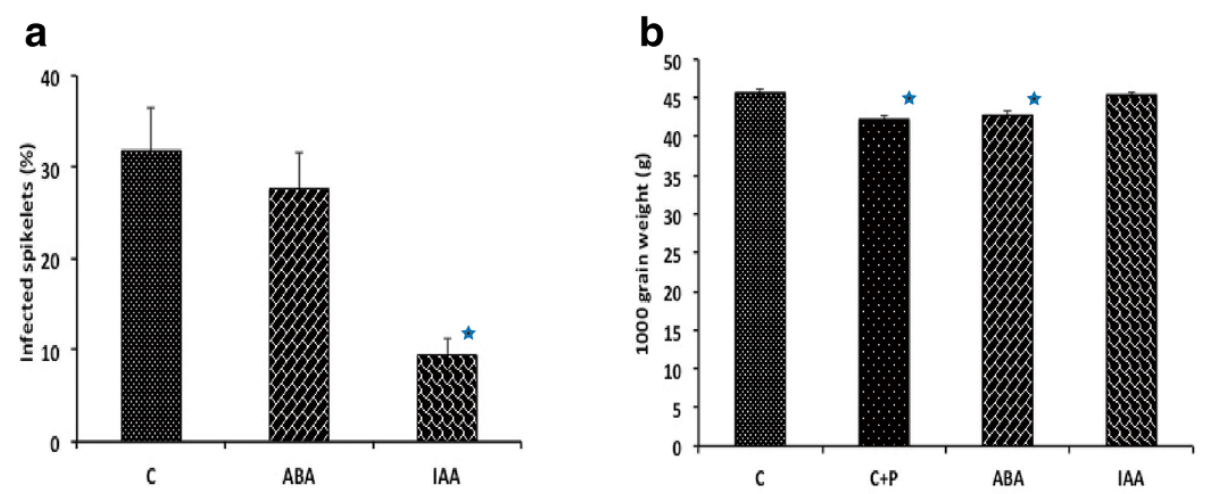

\section{C}

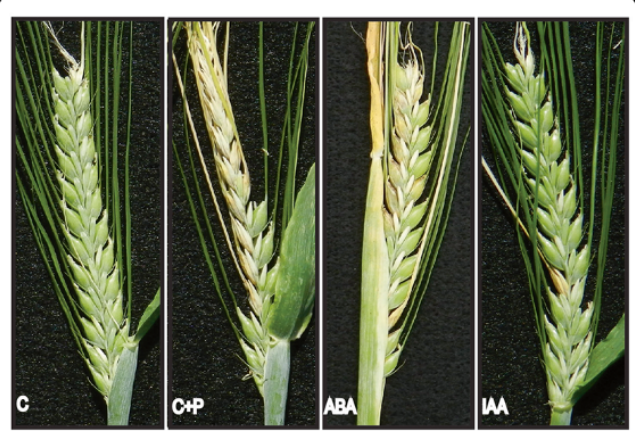

d

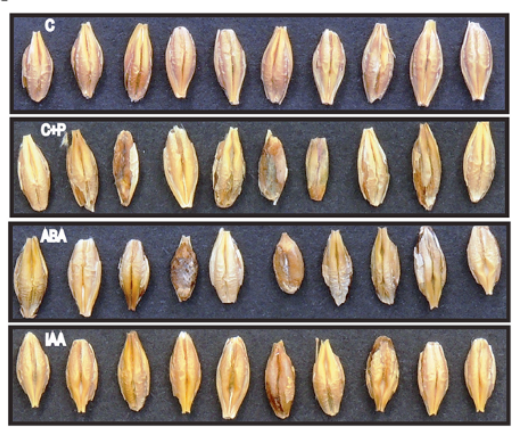

Figure 3 Exogenous application of IAA and ABA on FHB progression on barley treated heads and its effects on seed grain yields and quality. (a) Percentage of infected spikelets following IAA and ABA pre-Fusarium treatment. (b) A 1000 grain weight determined for the untretad water control (C) and the corrisponding pathogen exposed-IAA and ABA and the no-treatment head (C+P). (c) Fusarium head blight effects on barley heads for untreated control (C+P), IAA, ABA as compared to unexposed control (C). (d) Fusarium head blight effects on barley kernels. Treatment codes: C, controls treated with Tween20; C+P, controls treated with Tween20 plus pathogen (F. culmorum); IAA, indole-3-acetic acid; ABA, abscisic acid. Bars indicate standard error of mean. 
[30,31]. This motif is present in the A. thaliana NPR1 gene promoter [32], the product of which regulates both ISR (SA-independent) and SAR responses [33].

Auxin production was part of the response primed by P. fluorescens to respond to Fusarium infection and IAA reduced the severity of disease symptoms and associated yield loss when applied $24 \mathrm{~h}$ pre-pathogen. The increases in IAA observed herein in biocontrol plus pathogen treated tissue precede disease spread and thus are part of an early priming cascade activated in response to plant-pathogen contact. We found no evidence that either IAA or ABA inhibited fungal growth on PDA. $P$. fluorescens strain MKB158 has the capacity to produce auxin [34], as do Fusarium fungi [35]. Based on the literature [36-38], it is very possible that the IAA is derived from the bacterium and/or pathogen rather than the plant; the application of IAA might trick the plant into thinking it is being attacked by the pathogen, thus priming the defences responses such that they are activated to respond rapidly to the pathogen and thus increase plant FHB resistance. Fusarium culmorum displays a hemibiotrophic lifestyle [39] and there is evidence that auxin signalling enhances resistance to necrotrophs but susceptibility to biotrophs [40-42]. Noticeably, a recent report [43] highlights how auxin application was able to reverse hypersensitive response programmed cell death in tobacco initiated by a Erwinia amylovora type III elicitor harpin [43]. In a recent metabolomics study reports by Kumaraswamy et al. (2012), F. graminearum induced the accumulation of IAA in barley [44].

Most evidence points to ABA playing a negative role in plant disease resistance, although there are exceptions, particularly for necrotrophic pathogens (reviewed by Cao et al. [45]). But, it has a negative effect on some necrotrophs and therefore the role of ABA in the host response in not solely determined by the pathogen lifestyle. The predominance of ABA-responsive elements in the upstream region of primed genes, the previous association between $\mathrm{ABA}$ and primed biocontrol responses [46], its association with diverse pathogen resistances [47] and the increased ABA levels in bacterium and pathogen treated plants all provide "circumstantial" evidence that this hormone might play a role in the interplay between Fusarium and barley. Furthermore, there is evidence for a link between ABA and FHB resistance: callose deposition and repression of ethylene signalling are associated with ABA [12] and also with resistance to Fusarium spread in wheat spikelets [48-50]. Both the biocontrol agent and pathogen induced the accumulation of similar levels of ABA, indicating that any quantitative effects of this hormone on biotic responses are general rather than organism-specific. ABA itself did not reduce the severity of FHB. IAA activates the expression of the ABA biosynthetic gene NCED, as found by us and others [51]. Thus it is conceivable that application of IAA activates ABA-associated defences, but the converse does not occur; this warrants investigation. It could also be that the timing of application of ABA and the activation associated defence cascades were not optimal for disease control.

\section{Conclusions}

Defence responses are finely modulated by multiple hormones and herein we report of how the application of a biocontrol bacteria activated the in planta biosynthesis of two fundamental hormones, ABA and IAA. Studies that focus on the effect of specific components of IAA biosynthesis, homeostasis and turnover on defence priming will greatly enhance our understanding of how biocontrol pseudomonads can be used more effectively to control plant diseases. This study has identified IAA as a method for controlling FHB disease. Other studies have shown that IAA can reduce the severity of Fusarium seedling blight disease of wheat and barley (Khan et al., unpubl. data). Interestingly, it has been associated with systemic acquired immunity [52] and it has protective effects against apple scab caused by the necrotroph Botrytis cineria when applied pre- but not when applied post-pathogen [53]. IAA might offer a realistic treatment for the control of diseases such as FHB where crops have a limited and clearly defined infection (mid-anthesis for FHB). Thus the effect of IAA on mycotoxin accumulation in grain and on other agronomic parameters are worthy of investigation.

\section{Methods}

\section{Maintenance and culture of microorganisms}

The biocontrol bacterium used in this study was Pseudomonas fluorescens strain MKB158; this bacterium was chosen because of its ability to control FSB and FHB diseases of wheat and barley and to reduce mycotoxin contamination in the grain $[14,15]$. Culture conditions and inoculum preparation were as described in [14]. The phytopathogenic Fusarium culmorum (W. G. Smith) Sacc. strain FCF 200 (kindly supplied by Dr. Paul Nicholson, John Innes Center, Norwich, UK) was grown at $24^{\circ} \mathrm{C}$ on PDA plates. The maintenance of F. culmorum and the production of conidial inoculum $\left(10^{5}\right.$ conidia $\mathrm{ml}^{-1} 0.2 \%$ Tween20) were as described earlier [14].

\section{In silico analysis of gene promoters}

We previously identified genes that were primed by $P$. fluorescens to respond to attack by F. culmorum [17]. These were discriminated as transcripts differentially regulated only when both agents, i.e. the biocontrol bacterium and the pathogen, are present and are herein and after referred throughout the manuscript to as potentiated (see Additional file 1: Table S1 in [17]). The probe 
sequence corresponding to the potentiated genes was retrieved from the plant expression database (www. Plexdb.com). Additionally, BLAST analysis using the probe sequence identified homologous transcript assemblies (TAs) within the TIGR website (http://blast.jcvi. org/euk-blast/plantta_blast.cgi) (specified for the Liliopsida). Genomic sequences were identified based on BLAST analysis against the high throughput genomic sequences (HTGS) and the genomic survey sequences (GSS). The open reading frames were identified (http:// www.ncbi.nlm.nih.gov/projects/gorf/orfig.cgi) and thus the upstream 5'-sequences were deduced. Upstream regions (average length of $1 \mathrm{~kb}$ ) were scanned for cisacting elements which were associated with hormone induction, modulation or responsiveness using the Plant-Cis-Acting-Elements (PLACE) software (http:// www.dna.affrc.go.jp/PLACE/signalscan.html) [54,55].

\section{Fusarium head blight experiments}

The two-row spring barley (Hordeum vulgare L.) cultivar (cv.) Lux was used in this study (kindly supplied by Powerseeds, Kildare, Ireland). This cultivar is susceptible to FHB [15]. All head blight experiments were conducted in a non-climate controlled glasshouse and plants were grown to mid-anthesis at which point heads were treated. In all experiments heads were covered with a polythene bag immediately after fungal/Tween 20 treatment and plants were arranged in a randomised block design.

For experiments that analysed the effect of $P$. fluorescens on the accumulation of ABA and IAA in F. culmorum-infected heads, heads (two per plant) were treated with either bacterium, sterile water (controls), and $24 \mathrm{~h}$ later with either Tween 20 or F. culmorum, all as previously described [17]. Each treatment combination was applied to 10 plants ( 2 heads per plant) per harvest time point and this experiment was conducted twice between May and August 2008. For experiments that investigated the effect of hormones on gene expression, plants were grown as above and, at mid-anthesis, heads (two per plant) were sprayed to runoff with either indole acetic acid (IAA), absciscic acid (ABA), (Sigma, UK) in dimethyl sulfoxide (DMSO; $10 \mu \mathrm{gml}^{-1}$ ) or DMSO $\left(10 \mathrm{\mu gml}^{-1}\right)$ alone. Twenty-four hours post-hormone applications, the same heads were treated with either Tween 20 or F. culmorum, all as previously described by [17]. Each treatment combination was applied to four plants ( 2 heads per plant) per harvest time point and this experiment was conducted twice between May and August 2009. Heads were harvested at either 4, 12, 24 or $48 \mathrm{~h}$ post-fungal application, freeze-dried and stored at $-70^{\circ} \mathrm{C}$. Freeze-dried plant material was ground to a fine powder (the two heads harvested per plant were bulked) using a mortar and pestle and liquid nitrogen prior to either RNA or hormone extraction.
For experiments that investigated the effect of hormones on disease development, cv. Lux plants were grown and treated with either ABA or IAA and either pathogen or Tween 20 as above. Each treatment combination was applied to sixteen plants ( 2 heads per plant) and this experiment was conducted twice between Dec and June 2012. Disease was scored as the percentage of spikelets per head showing premature bleaching at growth stage (GS) 80 (start of dough development), as previously described [15]. At GS 90, heads were harvested, freeze-dried, and the 1000 grain weight was determined on per head basis.

\section{In vitro plate assay}

Potato dextrose agar (PDA) was amended with either IAA or ABA (Sigma, UK). Hormones were dissolved in DMSO and added at a final concentration of either $0,0.1,1,5,10$, 25, 50, $100 \mu \mathrm{g} \mathrm{ml}^{-1}$ PDA, DMSO concentration in all plates was adjusted to $1 \% \mathrm{wv}^{-1}$. Plates were inoculated with $5 \mathrm{~mm}$ diameter plug of $F$. culmorun strain FCF200, which was harvested from a seven-day-old PDA plate. Plates were incubated at $25^{\circ} \mathrm{C}$. After $72 \mathrm{~h}$, the diameter of the colony (in $\mathrm{cm}$ ) was measured. The experiment was carried out twice, each containing three technical replicate per treatmeant.

\section{Hormone analyses}

Hormone extracts were prepared from $250 \mathrm{mg}$ plant material using the protocol described by Dobrev et al., [56,57]. Indole acetic acid (IAA) and abscisic acid (ABA) were quantified by enzyme-linked immunosorbent analysis (ELISA) using the Olchemim C1 kits (Olchemim, Olomouc, Czech Republic). The procedure was conducted according to the manufacturer instructions, except that the incubation time was increased to $60 \mathrm{~min}$. Each ELISA analysis included IAA or ABA standards (From 3.9 to $0.061 \mathrm{pmol}$ ) (Olchemim, Olomouc, Czech Republic). Using the OD (405 nm) absorbance values, hormone concentrations were extrapolated from a standard curve that related the absorbance to concentration of either the IAA or ABA standard.

\section{RNA extraction and semi-quantitative real time PCR}

RNA was extracted from $200 \mathrm{mg}$ of plant material according to a modified hot-phenol procedure [58]. RNA was DNase-treated and quality was checked as previously described [17]. Real-time RT-PCR analysis was used to analyse the temporal expression of a selected subset of transcripts from the microarray studies completed previously [17]. Genes analysed were: a putative non-specific lipid transfer protein (nsLTP), a tonoplast aquaporin (TIP3:1), a subtilisin-chymotrypsin inhibitor (CI-1B), a zinc methallothionin-like protein (ZnMT), a serpin Z4 (Paz1), a nine-cis-epoxycarotenoid dioxygenase (NCED) and a 
signalling cascade protein (Pi2). The housekeeping gene used for normalisation of RT-PCR data was $\alpha$-tubulin (GenBank accession no. AJ132399.1); real-time RT-PCR analysis validated its constitutive expression (irrespective of treatment; results not shown). Real-time quantification of target transcripts and of the housekeeping gene was performed in separate reactions. Primers and PCR conditions were previously described [17]. The threshold cycle $\left(\mathrm{C}_{\mathrm{T}}\right)$ values obtained by real-time RT-PCR were used to calculate the accumulation of target (relative mRNA accumulation), relative to $\alpha$-tubulin transcript, with the formula $2^{-(\text {CT target transcript }- \text { CT } \alpha \text {-tubulin) }}[59]$.

\section{Statistical analysis}

Statistical analysis of the real-time RT-PCR and the hormone data was performed using Minitab 16 (Minitab Inc., State College, Pennsylvania, USA). Data were tested for normal distribution using the Kolmogorov-Smirnov normality test. Non-normally distributed data were analysed using the Kruskal-Wallis and Mann-Whitney Rank sum tests. Normally distributed data was analysed using a one-way analysis of variance (ANOVA) incorporating Tukey's pairwise comparison (5\% level of significance).

\section{Additional files}

Additional file 1: Table S1. Identification of hormone-responsive cisacting elements within the 5 '-region of barley genes potentiated by Pseudomonas fluorescens (strain MKB 158) to respond to attack by Fusarium culmorum (strain FCF200).

Additional file 2: Figure S1. Effect of hormones on the in vitro growth of Fusarium culmorum (strain FCF200) on potato dextrose agar.

\section{Competing interests}

The authors declare that they have no competing interests.

\section{Authors' contributions}

CP carried out the head blight experiment, collected and processed the samples including RNA extraction and RT-PCR and drafted the manuscript. KR completed the RT analyses and helped with the hormone extraction and the drafting of the manuscript. SSA carried out the head blight trials for disease assessment and the plate assays. MB contributed to the sample collection and the RNA extraction. FD conceived the study, helped with the design and experimentation, and with the drafting of manuscript. All authors read and approved the final manuscript.

\section{Acknowledgements}

This work was funded by the Irish Department of Agriculture Research Stimulus Fund RSF 06377 and Science Foundation Ireland principal investigator project 10/IN.1/B3028.

\section{Author details}

${ }^{1}$ Molecular Plant-Pathogen Interaction Group, School of Biology and Environmental Science, University College Dublin, Science Education and Research Centre West, Belfield, Dublin, Ireland. ${ }^{2}$ Current address: Department of Horticulture, Science Centre North, University of Kentucky, Lexington, Kentucky 40502, USA. ${ }^{3}$ UCD School of Biology and Environmental Sciences, Room 148, Science Education and Research Centre West, UCD, Belfield, Dublin 4, Ireland.

Received: 10 July 2012 Accepted: 29 October 2012

Published: 22 November 2012

\section{References}

1. Compant S, Duffy B, Nowak J, Clement C, Ait Barka E: Use of plant growthpromoting bacteria for biocontrol of plant diseases: principles, mechanisms of action and future prospects. Appl Environ Microbiol 2005, 71(9):4951-4959

2. Haas D, Blumer C, Keel C: Biocontrol ability of fluorescent pseudomonads genetically dissected: importance of positive feedback regulation. Curr Opin Biotechnol 2000, 11(3):290-297.

3. Pieterse CMJ, Van Pelt JA, Ton J, Parchmann S, Mueller MJ, Buchala AJ, Metraux JP, Van Loon LC: Rhizobacteria-mediated induced systemic resistance (ISR) in Arabidopsis requires sensitivity to jasmonate and ethylene but is not accompanied by an increase in their production. Physiol Mol Plant Pathol 2000, 57(3):123-134.

4. Van Wees SCM, Luijendijk M, Smoorenburg I, Van Loon L, Pieterse CM: Rhizobacteria-mediated induced systemic resistance (ISR) in Arabidopsis is not associated with a direct effect on gene expression of known defence-related genes but stimulates the expression of jasmonateinducible gene atvsp upon challenge. Plant Mol Biol 1999, 41:537-549.

5. Van der Ent S, Van Hulten M, Pozo MJ, Czechowski T, Udvardi MK, Pieterse $\mathrm{CM}$, Ton J: Priming of plant innate immunity by rhizobacteria and $\beta$ aminobutyric acid: differences and similarities in regulation. New Phytol 2009, 183:419-431.

6. Zehnder GW, Murphy JE, Sikora EJ, Kloepper JW: Application of rhizobacteria for induced resistance. Eur J Plant Pathol 2001, 107:39-50.

7. Zhang W, Gao S, Zhou X, Chellappan P, Chen Z, Zhou X, Zhang X, Fromuth $\mathrm{N}$, Coutino G, Coffey M, Jin H: Bacteria-responsive microRNAs regulate plant innate immunity by modulating plant hormone networks. Plant Mol Biol 2011, 75:93-105.

8. Bari R, Jones JD: Role of plant hormones in plant defence responses. Plant Mol Biol 2009, 69:473-88.

9. Conrath U, Pieterse CMJ, Mauch-Mani B: Priming in plant-pathogen interactions. Trends Plant Sci 2002, 7:210-216.

10. Van Loon L: Plant responses to plant growth-promoting rhizobacteria. Eur J Plant Pathol 2007, 119:243-254.

11. De Vleesschauwer D, Höfte M: Chapter 6 Rhizobacteria-Induced Systemic Resistance. In Advances in Botanical Research. USA: Publisher Academic Press; 2009:223-281.

12. Ton J, Mauch-Mani B: ß-amino-butyric acid-induced resistance against necrotrophic pathogens is based on ABA-dependent priming for callose. Plant J 2004, 38(1):119-130.

13. Robert-Seilaniantz A, MacLean D, Jikumaru Y, Hill L, Yamaguchi S, Kamiya Y, Jones JDG: The microRNA miR393 re-directs secondary metabolite biosynthesis away from camalexin and towards glucosinolates. Plant J 2011, 67(2):218-231.

14. Khan MR, Fischer S, Egan D, Doohan FM: Biological control of fusarium seedling blight disease of wheat and barley. Phytopathology 2006, 96(4):386-394.

15. Khan MR, Doohan FM: Bacterium-mediated control of Fusarium head blight disease of wheat and barley and associated mycotoxin contamination of grain. Biol Contr 2009, 48(1):42-47.

16. Khan MR, Doohan FM: Comparison of the efficacy of chitosan with that of a fluorescent pseudomonad for the control of Fusarium head blight disease of cereals and associated mycotoxin contamination of grain. Biol Contr 2009, 48(1):48-54.

17. Petti $C$, Khan M, Doohan F: Lipid transfer proteins and protease inhibitors as key factors in the priming of barley responses to Fusarium head blight disease by a biocontrol strain of Pseudomonas fluorescens. Funct Integ Genomics 2010, 10(4):619-627.

18. Koornneef M, Léon-Klosterziel KM, Schwartz SH, Zeevaart JAD: The genetic molecular dissection of abscisic acid biosynthesis and signal transduction in Arabidopsis. Plant Physiol Biochem 1998, 36:83-89.

19. Zeevaart JAD, Creelmann RA: Metabolism and physiology of abscisic acid. Annu Rev Plant Physiol Plant Mol Biol 1988, 39:439-473.

20. Ding $L$, Xu H, Yi H, Yang L, Kong Z, Zhang L, Xue S, Jia H, Ma Z: Resistance to hemi-biotrophic $F$. graminearum infection is associated with coordinated and ordered expression of diverse defense signaling pathways. PLoS One 2011, 6(4):e19008.

21. Yamada T: The role of Auxin in plant-disease development. Ann Rev Phytopatol 1993, 31:253-273.

22. Ton J, D'Alessandro M, Jourdie V, Jakab G, Karlen D, Held M, Mauch-Mani B, Turlings TCJ: Priming by airborne signals boosts direct and indirect resistance in maize. Plant $J$ 2009, 49:16-26. 
23. Kazan K, Manners JM: Linking development to defence: auxin in plantpathogen interactions. Trends Plant Sci 2009, 14:373-382.

24. Fan J, Hill L, Crooks C, Doerner P, Lamb CJ: Abscisic acid has a key role in modulating diverse plant pathogen interactions. Plant Physiol 2009, 150:1750-1761.

25. Flors V, Ton J, Van Doorn R, Jakab G, Garcia-Agustin P, Mauch-Mani B: Interplay between JA, SA and ABA signalling during basal and induced resistance against Pseudomonas syringae and Alternaria brassicola. Plant $J$ 2008, 54:81-92.

26. Chen Z, Agnew JL, Cohen JD, He P, Shan L, Sheen J, Kunkel BN: Pseudomonas syringae type III effector AvrRpt2 alters Arabidopsis thaliana auxin physiology. Proc Natl Acad Sci USA 2007, 104:20131-20136.

27. Lawton K, Weymann K, Friedrich L, Vernooij B, Uknes S, Ryals J: Systemic acquired resistance in Arabidopsis requires salicylic acid but not ethylene. MPMI 1995, 8(6):863-870.

28. Zhang Z, Li Q, Li Z, Staswick PE, Wang M, Zhu Y, He Z: Dual regulation role of GH3.5 in salicylic acid and auxin signaling during ArabidopsisPseudomonas syringae interaction. Plant Physiol 2007, 145(2):450-64.

29. Ding X, Cao Y, Huang L, Xu C, Li X, Wang S: Activation of the indole-3acetic-acid-amido synthetase $\mathrm{GH} 3-8$ suppresses expansin expression and promotes salicylate-and jasmonate-indipendent basal immunity in rice. Plant Cell 2008, 20:228-240.

30. Redman J, Whitcraft J, Johnson C, Arias J: Abiotic and biotic stress differentially stimulate as-1 element activity in Arabidopsis. Plant Cell Rep 2002, 21:180-185.

31. Klinedinst S, Pascuzzi P, Redman J, Desai M, Arias J: A xenobiotic-stressactivated transcription factor and its cognate target genes are preferentially expressed in root tip meristems. Plant Mol Biol 2002, 42:679-688.

32. Despres C, Chubak C, Rochon A, Clark R, Bethune T, Desveaux D, Fobert P: The Arabidopsis NPR1 disease resistance protein is a novel cofactor that confers redox regulation of DNA binding activity to the basic domain/ leucine zipper transcription factor TGA1. Plant Cell 2003, 15:2181-2191.

33. Pieterse CM, Van Loon L: NPR1: the spider in the web of induced resistance signaling pathways. Curr Opin Plant Biol 2004, 7(4):456-464.

34. Smyth EM, McCarthy J, Nevin R, Khan MR, Dow JM, O'Gara F, Doohan FM: In vitro analyses are not reliable predictors of the plant growth promotion capability of bacteria; a Pseudomonas fluorescens strain that promotes the growth and yield of wheat. J Appl Microbiol 2011, 111(3):683-692.

35. Tsavkelova EA, Klimova SY, Cherdyntseva TA, Netrusov Al: Microbial producers of plant growth stimulators and their practical use: a review. Appl Biochem Microbiol 2006, 42(2):117-126.

36. Kochar M, Upadhyay A, Srivastava S: Indole-3-acetic acid biosynthesis in the biocontrol strain Pseudomonas fluorescens Psd and plant growth regulation by hormone overexpression. Res Microbiol 2011, 162:426-435.

37. de Torres-Zabala M, Truman W, Bennett MH, Lafforgue G, Mansfield JW, Rodriguez Egea P, Bogre L, Grant M: Pseudomonas syringae pv. tomato hijacks the Arabidopsis abscisic acid signalling pathway to cause disease. EMBO J 2007, 26:1434-1443.

38. Kulkarni GB, Sajjan SS, Karegoudar TB: Pathogenicity of indole-3-acetic acid producing fungus Fusarium delphinoides strain GPK towards chickpea and pigeon pea. Eur J Plant Pathol 2011, 131:355-369.

39. Cuzick A, Lee S, Gezan S, Hammond-Kosack KE: NPR1 and EDS11 contribute to host resistance against Fusarium culmorum in Arabidopsis buds and flowers. Mol Plant Pathol 2008, 9(5):697-704.

40. Robert-Seilaniantz A, Navarro L, Bari R, Jones JD: Pathological hormone inbalances. Curr Opin Plant Biol 2007, 10:372-379.

41. Grant M, Jones JDG: Hormone (Dis)harmony moulds plant health and disease. Science 2009, 324:750-752.

42. Grant M, Lamb C: Systemic immunity. Curr Opin Plant Biol 2006, 9:414-420.

43. Gopalan S, et al: Reversal of an immunity associated plant cell death program by the growth regulator auxin. BMC Res Notes 2008, 1. doi:10.1186/1756-0500-1-126.

44. Kumaraswamy GK, Kushalappa AC, Choo TM, Dion Y, Rioux S: Differential metabolic response of barley genotypes, varying in resistance, to trichothecene-producing and-nonproducing (tri5) isolates of Fusarium graminearum. Plant Pathol 2012, 61:509-521.

45. Cao FY, Yoshioka K, Desveaux D: The roles of ABA in plant-pathogen interactions. J Plant Res 2011, 124(4):489-499.

46. Mauch-Mani B, Mauch F: The role of abscisic acid in plant-pathogen interactions. Curr Opin Plant Biol 2005, 8(4):409-414.
47. Asselbergh B, De Vleesschauwer D, Höfte M: Abscisic acid has a key role in modulating diverse plant-pathogen interactions. Mol Plant Microbe Interact 2008, 21(6):709-719.

48. Kang Z, Buchenauer $\mathrm{H}$ : Ultrastructural and immunocytochemical investigation of pathogen development and host responses in resistant and susceptible wheat spikes infected by Fusarium culmorum. Physiol Mol Plant Pathol 2000, 57(6):255-268.

49. Kang Z, Buchenauer $\mathrm{H}$ : Cytology and ultrastructure of the infection of wheat spikes by Fusarium culmorum. Mycol Res 2000, 104(9):1083-1093.

50. Chen X, Steed A, Travella S, Keller B, Nicholson P: Fusarium graminearum exploits ethylene signalling to colonize dicotyledonous and monocotyledonous plants. New Phytol 2009, 182(4):975-983.

51. Kraft M, Kuglitsch R, Kwiatkowski J, Frank M, Grossmann K: Indole-3-acetic acid and auxin herbicides up-regulate 9-cis-epoxycarotenoid dioxygenase gene expression and abscisic acid accumulation in cleavers (Galium aparine): interaction with ethylene. J Exp Bot 2007, 58(6):1497-1503.

52. Company P, Gonzalez-Bosch C: Identification of a copper chaperone from tomato fruits infected with Botrytis cinerea by differential display. Biochem Biophys Res Commun 2003, 304(4):825-830.

53. Yu T, Zhang H, Li X, Zheng X: Biocontrol of Botrytis cinerea in apple fruit by Cryptococcus laurentii and indole-3-aceti acid. Biol Contr 2008, 46:171-177

54. Higo K, Ugawa $Y$, Iwamoto M, Korenaga T: Plant cis-acting regulatory DNA elements (PLACE) database. Nucleic Acids Res 1999, 27(1):297-300.

55. Prestridge DS: SIGNAL SCAN: A computer program that scans DNA sequences for eukaryotic transcriptional elements. CABIOS 1991, 7:203-206.

56. Dobrev IP, Miroslav K: Fast and efficient separation of cytokinins from auxin and abscisic acid and their purification using mixed-mode solidphase extraction. J Chromatogr A 2002, 950(1-2):21-29.

57. Dobrev PI, Havlícek L, Vágner M, Malbeck J, Kamínek M: Purification and determination of plant hormones auxin and abscisic acid using solid phase extraction and two-dimensional high performance liquid chromatography. J Chromatogr A 2005, 1075(1-2):159-166.

58. Chang S, Puryer J, Cairney J: A simple and efficient method for isolating RNA from pine trees. Plant Mol Biol Rep 1993, 11:113-116.

59. Livak KJ, Schmittegen TD: Analysis of relative gene expression data using real-time quantitave PCR and the $2^{-\Delta \Delta C t}$ method. Methods 2001, 25:402-408

doi:10.1186/1471-2229-12-224

Cite this article as: Petti et al:: Auxin as a player in the biocontrol of Fusarium head blight disease of barley and its potential as a disease control agent. BMC Plant Biology 2012 12:224

\section{Submit your next manuscript to BioMed Central and take full advantage of:}

- Convenient online submission

- Thorough peer review

- No space constraints or color figure charges

- Immediate publication on acceptance

- Inclusion in PubMed, CAS, Scopus and Google Scholar

- Research which is freely available for redistribution 